\title{
GAME-BASED LEARNING IN ENGLISH FOR PROFESSIONAL PURPOSES
}

\section{Tatjana Marković}

\author{
Belgrade Business school \\ - Higher education institution \\ for applied studies, \\ Belgrade, Serbia
}

\begin{abstract}
:
This paper aims to explore the potentials of introducing game-based learning in English for Professional Purposes course at the tertiary level of education. It considers the possibilities of integrating an online business game in a taskbased experiential syllabus using simulation as its core technique. Simulations are seen as a viable, dynamic, communicative and learner-centered approach that enables creating the learning experience that resembles real-world professional experiences. By integrating language, content and skill development in meaningful and purposeful tasks that replicate workplace target tasks, simulations create an immersive and stimulating environment that fulfills the needs for competence, connectedness and autonomy, thus increasing learners' motivation.
\end{abstract}

Key words:

simulation, task-based learning, game-based learning, ICT.

"People learn a second language more successfully when they use the language as a means of acquiring information, rather than as an end in itself...

...People learn a second language most successfully when the information they are acquiring is perceived as interesting, useful, and leading to a desired goal" (Richards and Rodgers, 2001: 207; 209).

\section{INTRODUCTION}

The new Conceptual Age (Pink, 2005) requires the possession of complex competencies and skills for the integration in the contemporary globalized and competitive workplace arena. It asks for a critical consideration of existing teaching practices and a search for imaginative and innovative solutions for preparing students to become functional and successful participants in their future professional communities.

In the field of English for Professional Purposes, the $21^{\text {st }}$ century challenges necessitate the acquisition and development of complex communicative, language, cognitive, social and affective capabilities relevant in terms of workplace requirements. At the same time, there is a pressing need for learning to take place in a stimulative, enjoyable and exciting environment, as a critical element for awakening the motivation of the new game generation digital natives (Prensky, 2001:65).
Correspondence:

Maja Veljković Michos

e-mail:

mveljkovic@singidunum.ac.rs 
One of the emerging trends in general education at all levels, including the tertiary level, is game-based learning, an innovative, action-based approach, relying on experimentation, self-discovery and exploration, often advocated as the future of education.

The first part of this paper will describe the rationale for the use of game-based learning, with simulation at its core, in teaching English for Business Purposes. The second part will be devoted to the presentation and review of an online business simulation and exploration of the pedagogical potential for its integration with the existing non-digital simulation in a task-based syllabus.

The simulation format has been found to be a viable, holistic, learner-centered and meaningful instruction choice, well-adapted to the needs of language and professional communication in the future workplace (Huhta et al 2013).

It is believed that such an approach effectively prepares students for operating in the professional environment and leads to the acquisition of the pertinent jargon, a set of professional skills and a repertoire of language skills used in everyday informal interactions with colleagues (Gatehouse, 2001).

Using game-based techniques enables:

a) creating a learning experience that is closer to the world and the way digital natives think and act, including a strong fun and game element, offering excitement, challenges and cooperation;

b) bringing teaching and learning closer to real-world professional experiences, by integrating language, content and skills development in meaningful and purposeful replicas of target tasks.

There is strong evidence that game-based approaches increase motivation and lead to deeper and more comprehensive learning results, as will be shown in the next sections.

\section{GAME-BASED LEARNING - AN OVERVIEW}

It is beyond the scope of this paper to explore the intricate classification of games and the complex relationship between games and simulations. For our purpose, it is sufficient to note that simulations have been traditionally considered as types of games, that the earliest simulations were in fact war games, and their relationship remains close to this date (de Freitas, 2006:10). As the author de Freitas (de Freitas, 2006:11) observes, through a more general educational lens, what brings games and simulations together is the potential they offer for learning through play, learning in immersive micro-worlds.
Games and simulations have been widespread in the field of amusement and entertainment for thousands of years, yet their use in education and training appears to be of a later date, somewhere at the end of the $18^{\text {th }}$ century, primarily in the field of military training. In the 1950s they were introduced in management and business education, and from then on games and simulations have started gaining ground in a range of other disciplines (Ellington, Gordon, and Fowlie 2006::ix-x; Gredler, 2004:578; Klabbers, 2009:xi). Today we are witnesses of the massive development in the field of gaming and simulation and the growth in the variety of types and range of applications (Crookall 2010; de Freitas, 2006; Ellington, Gordon, and Fowlie 2006). Gaming and simulation is seen as "a promising, and rapidly expanding field of study", improving and evolving, "with new trends emerging, and new avenues of thought being explored" (USA Information Resources Management Association 2011: xxiv-xxv).

The potential of game-based learning is increasingly becoming appreciated based on numerous studies showing its effectiveness in cognitive development and curricular knowledge acquisition in new and innovative ways (de Freitas, 2006; Johnson, Smith, Levine \& Haywood, 2011: 2011: 21-22; Whitton \& Baek, 2013). Its positive effects also include affective and motivational outcomes, the development of perceptive as well as soft skills (Connolly et al, 2012:667; Wastiau, Kearney \& Van den Berghe, 2009).

Games and simulations enable the creation of an exciting learning experience by fostering collaboration, problemsolving and procedural thinking, key competences for the $21^{\text {st }}$ century (Johnson, Smith, Levine \& Haywood, 2011:5). They cultivate creative thinking, experimentation and positive attitude towards intensive changes in our modern society. They are goal oriented, have an interesting story and enable learning while socializing (ibid.). At the same time, in the spirit of social constructivism, they create a space respectful of individual learning styles and strategies and multiple intelligences, increasing motivation and leading to longer-lasting learning (IGI Global \& Felicia, 2011: x-xiii).

In higher education, they enable an integrated approach in acquiring content knowledge along with specific skills, such as decision-making, innovation, problem-solving and leadership (Johnson, Smith, Levine \& Haywood, 2011, 2011:21-22). They offer the transformation of the learning process through direct experience in an immersive environment. As new generations of learners want interactive relationship with materials of different modalities (Prensky, 2001), the introduction of game-based learning is becoming increasingly popular. Finding ways to capture its motivational force in the field of education and use it to advance the 
achievement of education goals has become the "holy grail" of teachers and practitioners (Garris, Ahlers \& Driskell, 2002:442) ${ }^{1}$.

GBL is gaining momentum and is increasingly becoming popular in the field of digital games, including so-called serious games, created solely for educational purposes, as well as in the area of long existing non-digital games.

In the domain of foreign language learning, games and simulations are not a recent fad and have been used since the 1980s and the emergence of the communicative approach (Coleman, 2002). The use of games and simulations in EFL, both digital and non-digital, has been widely documented (Crookall \& Oxford, 1990; Dupuy, 2006; García-Carbonell, Andreu-Andrés \& Watts, 2014; Levine, 2004; Magge, 2006; Naidu, 2007). However, they are coming into vogue again, as we are witnessing a rise in interest for using games in EFL, including adaptations of existing commercial games for the needs of foreign language courses.

Some studies explore the implementation of Alternate reality games - ARGs, such as The Tower of Babel, aimed at promoting foreign language learning in schools in a joint European project involving 300 students in 17 countries (Connolly, Stansfied \& Hainey, 2011) and the use of interactive fiction in textual adventures (Pereira, 2013). Furthermore, the commercial computer game/simulation, the SIMS, which emulates everyday life and activities, has been used in several studies that looked into its impact on vocabulary acquisition of university students, showing its positive effect as a complementary activity in lexical acquisition (Miller \& Hegelheimer, 2006; Ranalli, 2008).

In their analysis of vocabulary acquisition and retention using lexical games among students of engineering, Yip and Kwan (2006) have demonstrated not only increased student interest and motivation, but also improved success and effectiveness in reaching learning outcomes. At the same time, a growing body of research is being done on the use of virtual worlds, such as Second Life, There, and similar, synthetic immersive environments with possibilities of voice chat, which might be quite effective in foreign language learning (Ranalli, 2008:453).

1 However, there are authors who believe that accurate results of game-based learning in the cognitive and subject matter sense are difficult to determine, as different studies use different methodological approaches, different classification of competences and skills and diverse terminological solutions. Furthermore, instruments for the precise measuring of learning outcomes of GBL are still inadequate, as it is much more complex than traditional learning (see Wastiau, Kearney \& Van den Berghe, 2009 for a literature review on games in primary and secondary education, and Connolly et al, 2012 for a comprehensive overview of relevant studies dealing with games in higher education).
In the next section we are going to explore simulation as a technique, both in its non-digital version and the possibilities for integrating it with a digital format.

\section{SIMULATIONS - OVERVIEW}

Simulations are gaining high status in institutions of higher education. The main reason for their rising popularity in the field of foreign language teaching is the fact that they integrate both the communicative and the interactional aspects of language.

They create a micro-world mirroring and modeling multi-dimensional aspects of the real world and offering students pathways for discovering its principles and relations (Rieber, 1996). Simulations represent a safe ambience for learning and trying out different competencies and skills in a world that is imaginary, yet with functions that are realistic. The scenario-based opportunities encourage various social interactions and learning transactions, whereas role play and character identification make the learning experience in immersive environments effective and stimulating (de Freitas, 2006:44).

In terms of the linguistic methodological approach, they belong to the realm of TBLT, which is oriented towards the primacy of meaning in the completion of tasks and achieving non-linguistic goals related to real-life professional goals. Tasks have tangible outcomes, clear purpose and a real context (Skehan 1996:38).

Being a highly versatile and flexible technique, simulations can be easily adapted to the needs of English for Professional Purposes and they are particularly suitable for intermediate and advanced level students in activating, consolidating and reinforcing existing competences and skills. They create an extremely powerful environment for promoting the development of the students' verbal repertoire.

For these reasons simulation as a technique has already been implemented in our English for Business Purposes course at the Belgrade Business School, enabling us intercurricular integration and the parallel development of communicative, content, interpersonal, social and cognitive competences and skills, while at the same promoting creativity, cooperation and teamwork as the key elements for professional success and performance. In addition, simulation as a technique enables the creation of a playful environment which results in a highly inspiring and engaging experience contributing to successful learning. 


\section{THE COMPANY SIMULATION - DESIGN, STRUCTURE AND IMPLEMENTATION}

The Company Simulation, developed for our first-year students, revolves around tasks and subtasks related to some of the typical situations and experiences that may arise in the professional target culture and future workplace: setting up companies, dividing company roles and recruiting personnel, attending a trade fair. It includes different business interactions and transactions, such as exchanging telephone calls and e-mails, requesting information, making quotations, placing orders and socializing with foreign guests and associates.

It is an attempt to recreate a representation of the business world reality in which students act out their chosen business roles, in line with Jones'(1982:5) definition of simulation as "a reality of function in a simulated and structured environment".

The Company Simulation has six stages. Each stage of the simulation project begins with a briefing, and ends with a debriefing session. The briefing session provides an opportunity to introduce the tasks, bring attention to specialist vocabulary and useful expressions (Bullard, 1990:59-60), and to activate students' content, linguistic and socio-cultural background knowledge (Knutson, 2003:56-57).

The debriefing session, which is part of the reflection process, is an indispensable pre-requisite for successful experiential learning to take place, the key to the transformation of practical experience into knowledge (Kolb 1984:38). It is a reconstruction of the learning experience, its success and its challenges (Bullard, 1990; Jones, 1982; Knutson, 2003). It reinforces learning through meta-reflection and making connections between game activities and tasks with those performed in the real world and sets the stage for corrective work.

The tasks in the Company Simulation revolve around different communicative situations stimulating communication and information exchange. The tasks have tangible outcomes and clear and meaningful purposes that require information gathering, decision-making, knowledge sharing and negotiating of meaning in bridging information gaps and resolving problem-solving situations.

The first stage is devoted to the building of the conceptual framework for company set-ups, organizational structure and departmental responsibilities. Mixed-ability student teams fulfill the task of establishing their virtual companies, choosing their names and headquarters, business operations and business missions, along with the delegation of appropriate roles (general manager, marketing manager, financial manager, etc.). This stage ends in short company presentations aimed at engaging and sustaining student motivation in further work, and sets the stage for the phases to come.

Stage two is built around designing CVs and cover letters for the chosen company positions. In order to relax the atmosphere, boost creativity and imagination, students are allowed to either keep their own identity in the Simulation or create a new one, a role which will make them feel secure and free to experiment and communicate without feeling stress and anxiety.

In phase three students prepare for attending a business fair by practicing different business interactions, such as booking flights and accommodation, making contacts with prospective business associates, conducting formal and informal social interactions in establishing rapport with colleagues and clients, with the objective of closing business deals with other student teams. This is an introduction to phase four were companies exchange e-mails and phone calls in the process of developing and finalizing the business deal.

The Simulation project closes with oral presentations of all the companies, exhibiting all their activities and transactions, and the submittal of a portfolio containing the documents generated throughout the simulation: CVs, e-mails and planners, as well as the students' journals registering their progress in the execution of tasks.

\section{COMPANY SIMULATION REVISITED - AN INTRODUCTION TO VIRTONOMICS}

The next step in enhancing the learning experience using the simulation technique lies in enriching the non-digital Company Simulation by integrating it with an online business simulation.

We believe that in ESP the biggest promise of GBL lies in the use of digital games and simulations originally developed for educational purposes in the professional subject areas. To be more precise, in teaching English for Professional, Business and Computer science Purposes, using business and entrepreneurial simulations such as Virtonomics (www. virtonomics.com) or Entrepreneurship Simulation: The Startup Game ${ }^{2}$ may be most appropriate as complementary parts of the existing syllabus.

As the Virtonomics simulation is available for free use over the Internet we have decided to explore its learning potential and appropriateness with respect to the acquisition of language and content knowledge.

2 https://cb.hbsp.harvard.edu/cbmp/product/WH0001-HTM-ENG 
Virtonomics has managed to combine the educational and leisure aspects of game playing and having fun along with learning. It is a web-based online business simulator, a business strategy game, providing a framework for creating and developing a business. It represents a simulated virtual economy, based on real world economy and its business and managerial principles. It brings together more than one million players worldwide, creating a real businessoriented community with participants coming from all walks of life, businessmen, entrepreneurs, university and college students.

The aim of the game is to create a profitable and competitive enterprise. At the outset each player receives startup capital and is helped out during the initial period with different bonuses. However each virtual business owner is free in the choice of how to use and spend this money and which business goals to pursue.

Being a flexible and creative game, players are not limited to a single scenario; there are a variety of options to explore, each within a different realm, different industry, different strategic approach. From the outset, as a player, you build and manage your startup in an industry chosen among a variety of diverse options, both in terms of field of operation and type of enterprise. You can opt for retail business, manufacturing, medicine, automotive industry, oil refinery, sport equipment production, or something else, in Russia, Saudi Arabia, Argentine, you name it.

The games unifies 17 interconnected main business processes, 141 subsidiaries, 5 macro industries, 203 products, 33 countries, 300 cities. As a non linear environment, it allows each player to follow his or her own business path. Yet at the same time, he/she is a "part of a rapidly growing economy" with all the actions interconnected and created by real people, whether it is developing a business, forming partnerships, trading, purchasing or selling enterprises (virtonomics.com). Although the game is virtual, people and their interactions and transactions are real. Just like in real life you can try out different scenarios, and depending on your knowledge, persistence and experience, you can prosper or go bankrupt. The success of the business relies on your game actions. This involves making strategic and tactical decisions on a daily basis and judging the effectiveness of your campaigns, diversification, choice of suppliers, field of operations. It asks for constant market research, hiring, training and managing employees, investing in marketing, introducing technological innovations, improving the product quality, choosing the right partners, providing client satisfaction in order to start making a profit and rise to the top, so picking your niche and staying on edge is a must.

\section{LEARNING BENEFITS OF VIRTONOMICS}

Virtonomics is an excellent online environment for developing both hard and soft business skills, for making connections and communicating while still having fun.

It is a collaborative community, an environment with people willing to share their knowledge, experience and business acumen in helping newbies implement business strategies and develop their companies. Despite an essentially competitive nature of the game, players are willing to help each other out with advice. Furthermore, the game provides helpful resources such as forums, wikis- help files, guides, videos etc.

Its learning value lies in the fact that you can see results of your business decisions very quickly, much faster than in the real world. This enables you to adjust your moves daily in the struggle for a bigger market share and higher profit.

However, the important question remains and that is whether you can learn to do business by playing a game.

The authors of the game believe you can improve your entrepreneurial skills, and that playing a game where you can explore the consequences of making pricing, marketing and managerial decisions in a realistic environment in terms of competition and market conditions in a risk-free environment, can contribute in many ways in testing out your strategies and improving your business skills. You can also improve decision making in complex situations, analytical thinking, administrative skills and so on.

By combining the classroom Company Simulation with Virtonomics, where students could set up their companies in the virtual business community and follow their enterprises' progress based on managerial decisions and insight, we could take this English for Professional Purposes project one step further ahead, both in the area of professional competences and English competences development.

\section{CONCLUDING REMARKS: CHALLENGES AND OPPORTUNITIES OF GBL}

Language-wise, the Simulation leads to the practice, development and integration of all language skills through negotiation and cooperation in conquering different communicative challenges posed by various situations and interactions. The presence of non-linguistic outcomes that take the focus away from the language, inspires natural interactions and the use of different communicative strategies in overcoming communication barriers and information gaps, which has proven to be an effective pedagogical approach. 
Interactional authenticity, relevance and pertinence for the future workplace make simulations a method of choice in English for Professional purposes. Tasks in simulations are contextualized, meaningful and purposeful, mirroring real life communicative challenges and they enable developing and consolidating both linguistic and professional competences. In terms of language development, adding the business simulation accelerates the lexical acquisition process, with important specialist vocabulary acquired in context.

Both the classroom and the digital version of the simulation are interactive formats, fostering cooperation and leading to the development of social and interpersonal skills, as well as affective ones. In other words, simulations activate analytical and creative, intellectual, social and emotional potential of learners (Crookall \& Saunders, 1989; Oxford \& Crookall 1990). Teamwork, collaboration and cooperation, tenets of social constructivism (Vygotsky 1978/1997), enable peer learning, and a shared experience of discovery and exploration (Breen \& Candlin 1980:95), in both the digital and the non-digital simulation environment.

The classroom atmosphere in a simulation is safe and risk-free, lowering the affection filter and encouraging risktaking, an important element in language learning. The setting is relaxed and light-hearted, reducing shyness and self-consciousness. Fun and excitement, creativity and imagination, with all the attention focused on the task and complete involvement and immersion in the game world, create a sense of flow, the optimal learning experience that arises in the delicate zone between boredom and anxiety (Csikszentmihalyi, 1975:35-36). This state, a pre-requisite for successful learning (Goleman, 2008:89), is important for ESP as well, since, albeit a practical approach, ESP should also include elements of "enjoyment, fun, creativity and a sense of achievement" (Hutchinson and Waters 1987: 48).

As an active pedagogical approach, the Simulation cultivates learner autonomy and independence, enabling students to make their own decisions and take control of their learning process. The format respects individual learning styles and strategies in planning and evaluating learning, thus giving students the sense of responsibility, achievement, self-efficacy and self-esteem. It raises the students' interest, stake, engagement and investment in their work, instills inspiration and motivation, promotes deeper learning (Crookall 1990:157), and thus epitomizes many aspects of the holistic and humanistic approach in learning.

In a psychological sense, games fulfill the requirements for awakening intrinsic motivation, as they satisfy the need for competence (the sense of ability), the need for autonomy (independent decision-making) and the need for connect- edness in a social sense (Przybylski et al., 2010:155-157), the so called key elements of PENS- player experience of need satisfaction. This type of project would enable a) the development and application of competences, linguistic and specialist; b) the freedom and flexibility in decision-making and choice of strategies for reaching the desired goal; c) connectedness with other "players" through cooperation and competition, with an additional added value, and that is immersion into the world of "game".

In a professional sense, simulations bridge the gap between theory and practice, knowledge and action which is one of the cornerstones of education aimed at preparing students for the workplace arena. Using simulations, students at the tertiary level of education are given an opportunity to practice "the various multi-faceted, work-related skills that they will require once they enter employment" (Ellington, Gordon and Fowlie 2006:107). They practice the communicative skills and the professional knowledge and skills acquired in economic and business subjects through a simulated and accelerated "first-hand experience", offering skill transfer and developing lifelong learning skills.

Yet, still "a key challenge for designers" is how "to get the correct balance between delightful play and fulfilling specified learning outcomes" (de Freitas, 2006:5), how to integrate educational elements in the natural course of the game without killing the game, on the hand, and on the other hand, how to include the reflective element which would lead to a purposeful and learning game, and not just remain on the behavioral level where tasks are solved through trial and error (Kiili, 2005:14).

In foreign language learning this translates to the following: mirroring successful classroom techniques often does not result in an interesting gaming format, and on the other hand, a fun and entertaining game with no tutoring elements does not lead to effective learning and ends in the entertaining experience (Purushotma, Thorne, \& Wheatley, 2008; Whitton \& Baeck, 2013: xiii-xiv).

How we learn through play is still an open question, and the results of empirical studies and their meta-reviews are often inconclusive. The pressing question is what exactly is learning and how can learning outcomes be specified and measured in a valid and reliable way. As learning in immersive environments is complex and sophisticated, based on experience, interactions, and interchanges of various sorts, the learning outcomes are more wide-ranging and cross-disciplinary and much more difficult to assess and evaluate using standard procedures. However, at the same time they are potentially more rich and applicable to real world experiences (de Freitas, 2006:18), and having in mind all the potential educational opportunities offered 
by game-based learning, we strongly believe simulations deserve a highly prominent place in teaching English for Professional Purposes.

\section{REFERENCES}

Breen, M. P. \& Candlin, C. (1980). The essentials of a communicative curriculum in language teaching. Applied Linguistics, 1(2), 89-112.

Bullard, N. (1990). Briefing and debriefing. In D. Crookall \& R. L. Oxford (Eds.), Simulation, gaming and language learning (pp. 55-67). New York: Newbury House.

Coleman, D.W. (2002). On foot in SIM CITY: Using SIM COPTER as the basis for an ESL writing assignment. Simulation \& Gaming, 33(2), 217-230.

Connolly, T. M., Boyle, E., Boyle, J., Macarthur, E., \& Hainey, T. (2012). A systematic literature review of empirical evidence on computer games and serious games. Computers \& Education, 59(2), 661-686. https://www.cs.auckland.ac.nz/courses/ compsci747s2c/lectures/paul/LitReview_EmpiricalEvidence_SeriousGames.pdf (10.10.2015.)

Connolly, T.M., Stansfield, M. \& Hainey, T. (2011). An alternate reality game for language learning: ARGuing for multilingual motivation. Computers \& Education, 57(1), 1389-1415.

Crookall, D. (1990). International relations: specific purpose language training. In D. Crookall, D. \& R. L. Oxford (Eds.), Simulation, gaming, and language learning (pp.151-158). New York: Newbury House.

Crookall, D. (2010). Serious games, debriefing, and simulation/gaming as a discipline. Simulation \& Gaming, 41(6), 898-920.

Crookall, D. \& Oxford, R.L. (Eds.), (1990). Simulation, gaming, and language learning New York: Newbury House

Crookall, D., \& Saunders, D. (1989). Towards an integration of communication and simulation. In D. Crookall \& D. Saunders (Eds.), Communication and simulation: From two fields to one theme (pp.3-29). Clevedon, UK: Multilingual Matters.

Csikszentmihalyi, M. (1975). Beyond boredom and anxiety. San Francisco: Jossey- Bass.

De Freitas, S. (2006). Learning in immersive worlds. Joint Information Systems Committee.http://www.jisc. ac.uk/media/documents/programmes/ elearninginnovation/gamingreport_v3.pd]. 14/02/16.

Dupuy, B. (2006). L'Immeuble: French language and culture teaching and learning through projects in global simulation. In G. H. Beckett \& P.C. Miller (Eds.), Project-based second and foreign language education: Past, present and future (pp.195-214). Greenwich, Connecticut: Information Age Publishing.
Ellington, H., Gordon, M., \& Fowlie, J. (2006). Using games and simulations in the classroom. London: Biddles Ltd.

García-Carbonell, A., Andreu-Andrés, M. A., \& Watts, F. (2014). Simulation and gaming as the future's language of language learning and acquisition of professional competences. Back to the Future of Gaming, Germany: WB Verlag, 214-227.

Garris, R., Ahlers, R., \& Driskell, J. E. (2002). Games, motivation, and learning: A research and practice model. Simulation \& Gaming, 33(4), 441-467.

Gatehouse, K. (2001). Key issues in English for specific purposes (ESP) curriculum development. Internet TESL Journal, 7(10), 1-10.

Goleman, D. (2008). Emocionalna inteligencija. Geopoetika. Beograd.

Gredler, M. E. (2004). Games and simulations and their relationships to learning. In D. H. Jonassen (Ed.), Handbook of research for educational communications and technology (2nd edition) (pp. 571-581). Mahwah, NJ: Lawrence Erlbaum \& Associates.

Huhta, M., Vogt, K, Johnson, E \& Tulkki, H. (2013). Needs analysis for language course design. Cambridge: Cambridge University Press.

Hutchinson, T., \& Waters, A (1987). English for Specific Purposes: A learner-centered approach. Cambridge: Cambridge University Press.

IGI Global., \& Felicia, P. (2011). Handbook of research on improving learning and motivation through educational games: Multidisciplinary approaches. Hershey, Pa.: IGI Global.

Johnson, L., Smith, R., Willis, H., Levine, A., \& Haywood, K. (2011). The 2011 Horizon Report. Austin, Texas: The New Media Consortium. http://net.educause. edu/ir/library/pdf/HR2011.pdf (12.05.2015.)

Jones, K. (1982). Simulations in language teaching. Cambridge: Cambridge University Press.

Kiili, K. (2005). Digital game-based learning: Towards an experiential gaming model. The Internet and Higher Education, 8(1), 13-24.

Klabbers, J. H. G. (2009). The magic circle: Principles of gaming and simulation (3rd and revised edition). UK: Sense Publishers.

Knutson, S. (2003). Experiential learning in secondlanguage classrooms. TESL Canada Journal, 20(2), 52-64.

Kolb, D. A. (1984). Experiential learning: Experience as the source of learning and development. Englewood Cliffs, NJ: Prentice-Hall.

Levine, G. (2004). Global simulation: A student-centered task-based format for intermediate foreign language courses. Foreign Language Annals, 37(1), 26-36. 
Magge, M. (2006). State of field review: Simulation in education. Alberta Online Learning Consortium Calgary AB. (07.06.2015.)

Miller, M., \& Hegelheimer, V. (2006). The SIMs meet ESL incorporating authentic computer simulation games into the language classroom. International Journal of Interactive Technology and Smart Education, 3(4). 311-328.

Naidu, S. (2007). Transporting GOLDEN RICE to Malaysian classrooms. Simulation \& Gaming. 38, 344351.

Oxford, R. L., \& Crookall, D. (1990).Learning strategies. In D. Crookall \& R. L. Oxford (Eds.), Simulation, gaming, and language learning (pp. 109-117). New York: Newbury House Publishers.

Pereira, J. (2013). Beyond hidden bodies and lost pigs: Student perceptions of foreign language learning with Interactive Fiction. In Whitton, N. \& Baek, Y. (2013). Cases on digital game-based learning: methods, models, and strategies. Hershey, Pennsylvania: IGI Global. 50-80

Pink, D. H. (2005). A whole new mind: Moving from the information age to the conceptual age. New York: Riverhead Books.

Prensky, M. (2001b). Digital game-based learning. McGraw-Hill, New York.

Przybylski, A. K., Rigby, C. S., \& Ryan, R. M. (2010). A motivational model of video game engagement. Review of General Psychology, 14(2), 154-166.

Purushotma, R., Thorne, S. L., \& Wheatley, J. (2008). 10 key principles for designing video games for foreign language learning. https://lingualgames.wordpress.com/article/10-key-principles-for-designingvideo-27mkxqba7b13d-2/ (10.10.2015.)

Ranalli, J. (2008). Learning English with “The Sims”: Exploiting authentic computer simulation games for L2 learning. Computer Assisted Language Learning, 21(5), 441-455.
Richards, J. C., \& Rodgers, T. S. (2001). Approaches and methods in language teaching (2nd edition.). Cambridge, New York: Cambridge University Press.

Rieber, L. P. (1996). Seriously considering play: Designing interactive learning environments based on the blending of microworlds, simulations, and games. Educational Technology Research \& Development, 44(2), 43-5.

Skehan, P (1996). A framework for the implementation of task-based instruction. Applied Linguistics, 17(1), 38-62.

USA Information Resources Management Association (2010). Gaming and Simulations: Concepts, Methodologies, Tools and Applications. Hershey, PA: IGI Global.

Vygotsky, L. (1978). Interaction between learning and development. From:Mind and Society (pp.79-91). Cambridge, MA: Harvard University Press. Reprinted in: M. Gauvain \& M. Cole (1997). Readings on the Development of Children (2nd edition) (pp 29-36).

Wastiau, P., Kearney, C. \& Van den Berghe, W. (2009). How are digital games used in schools? Synthesis Report. European Schoolnet.

http://games.eun.org/upload/gis-synthesis_report_ en.pdf (05.11.2015.)

Whitton, N. \& Baek, Y. (2013). Cases on digital gamebased learning: methods, models, and strategies. Hershey, Pennsylvania: IGI Global. www.virtonomics.com

Yip, F. W. M., \& Kwan, A. C. M. (2006). Online vocabulary games as a tool for teaching and learning English vocabulary. Educational Media International, 43(3), 233-249. 